\section{Integrative Medicine \\ International}

Integr Med Int 2014;1:32-43

\section{DOI: $10.1159 / 000362629$}

Receivea: September 13, 2013

Accepted after revision: October 5, 2013

Published online: May 23, 2014

This is an Open Access article licensed under the terms of the Creative Commons AttributionNonCommercial 3.0 Unported license (CC BY-NC) (www.karger.com/OA-license), applicable to the online version of the article only. Distribution permitted for non-commercial purposes only.

\title{
Rotigotine Transdermal Patch for the Treatment of Restless Legs Syndrome
}

\author{
Pietro Lucca Ratti ${ }^{\text {b-e }}$ María Verónica Rey ${ }^{a}$ Olivier Rascol ${ }^{\text {b-e }}$ \\ Santiago Perez-Lloret ${ }^{a}$ \\ a Laboratory of Clinical Pharmacology and Epidemiology, Pontifical Catholic University \\ of Argentina, Buenos Aires, Argentina; Departments of ${ }^{b}$ Clinical Pharmacology and \\ 'Neurosciences, University Hospital and University of Toulouse, dINSERM CIC 9023, and \\ e UMR 825, Toulouse, France
}

\section{Key Words}

Restless legs syndrome · Dopamine agonists $\cdot$ Rotigotine $\cdot$ Safety $\cdot$ Efficacy

\begin{abstract}
Rotigotine, a nonergot dopamine agonist, has been developed as a novel transdermal formulation. The rotigotine transdermal patch has received EMA and FDA marketing authorization for the treatment of adult patients with early or advanced Parkinson's disease or with moderate-to-severe restless legs syndrome (RLS). This review comprises an overview of the pharmacokinetics, the pharmacodynamics and the clinical efficacy and safety of the rotigotine transdermal patch for RLS. Its source material was identified by a PubMed search for the terms 'rotigotine' and 'RLS'. The rotigotine transdermal patch demonstrates clinical efficacy alongside a good tolerability profile. Application site reactions were the most frequent adverse events, and they were considered mild to moderate in the majority of cases. In summary, the rotigotine transdermal patch offers a safe and efficacious alternative for the treatment of RLS. Further studies should focus on the possibility that continuous dopamine stimulation by means of transdermal patches might have an influence on RLS augmentation rates.
\end{abstract}

(C) 2014 S. Karger AG, Base

\section{Introduction}

The restless legs syndrome (RLS), also known as Ekbom's syndrome or anxietas tibiarum, is a sensorimotor disorder characterized by a nearly irresistible urge to move the lower limbs (less frequently the upper limbs), usually associated with a discomfort sensation deep inside the limbs. 
The estimated prevalence of RLS in the general population is around $7.3 \%$, and $2.7 \%$ of these patients suffer from moderately or severely distressing symptoms at least twice weekly. The prevalence of RLS increases with age and it tends to be two-fold more common in women than in men [1]. Idiopathic forms of RLS tend to show a familial pattern, with a familial aggregation rate of $40-50 \%$ [2], and tend to segregate in an autosomal dominant fashion with high penetrance [3].

Patients suffering from RLS may complain of uneasiness, nervousness, paresthesias, ache or a feeling which they find difficult or impossible to describe. Rest or inactivity, especially when lying or sitting in the evening or at night, typically worsens these symptoms, which can become particularly troublesome in situations such as travelling on a train or plane or sitting in a cinema or theater. RLS symptoms are typically relieved by movement such as walking or stretching but tend to reappear as the subjects stop moving [2]. A circadian pattern of occurrence and severity of RLS symptoms has also been described, with a maximum at nighttime $[4,5]$. Severe cases are associated with occurrence of symptoms at rest during both nocturnal and diurnal hours [2].

Around $94 \%$ of patients report sleep-onset insomnia or nocturnal awakenings due to RLS-related symptoms. These complaints match up with disrupted sleep on polysomnography [6]. RLS is frequently associated with the presence of periodic limb movements (PLM) during sleep (PLMS) or waking, conditions characterized by stereotyped repetitive movements occurring at rest which typically involve extension of the big toe, often in combination with partial flexion of the ankle, the knee and sometimes the hip [2].

RLS results in a reduced quality of life as well as in a social and economic burden [1, 7]. Sleep disruption due to RLS might, though not invariably, result in daytime sleepiness or fatigue. Deficits in cognitive functions sensitive to sleep deprivation have also been detected in patients with RLS $[8,9]$. Furthermore, RLS and PLMS are associated with sympathetic hyperactivity, resulting in arterial hypertension and an increased risk of cardiovascular and cerebrovascular diseases $[10,11]$.

RLS can present as an isolated phenomenon (i.e. idiopathic forms) or secondary to other medical conditions [2]. Among the latter forms, the one associated with iron deficiency anemia is by far the most common. Other conditions associated with iron deficiency, such as end-stage renal disease, pregnancy, low-density lipoprotein apheresis and gastric surgery, can also be responsible for secondary RLS. Associations of RLS with renal failure, peripheral neuropathy, Crohn's disease, fibromyalgia and rheumatoid arthritis have been reported as well. Finally, RLS or PLMS may be induced or aggravated by certain substances or medications like neuroleptics, tricyclic antidepressants, lithium carbonate, centrally active antihistamines and alcohol [12].

Several pieces of evidence seem to suggest multiple interacting mechanisms underlying this disease, involving, for instance, several cortical and subcortical brain structures, the spinal cord, the peripheral nervous system, some biochemical pathways and neurotransmitter systems. Nevertheless, the exact pathophysiology of RLS has not been clearly elucidated so far, the 'puzzle' being far from solved [13].

The most compelling clues to RLS pathophysiology probably come from clinical experience and point to a role of iron metabolism and the dopaminergic system. Dopamine agonists and levodopa provide symptomatic relief in mostcases, and dopamine agonists are considered the first-line option in patients requiring symptomatic pharmacological treatment [14]. On the other hand, drugs antagonizing dopamine transmission can induce or exacerbate RLS symptoms [12].

It has been suggested that a dysfunction of the dopaminergic neurons of the hypothalamic A11 area modulating spinal cord neurons (i.e. the diencephalospinal pathway) might contribute to explaining both the sensory and motor aspects of RLS [15]. Axons of A11 dopa- 
minergic neurons arrive at the dorsal horn and then project to the motor neuronal site. Downregulation of the inhibition at the spinal level due to dysfunction of A11 dopaminergic neurons might be responsible for impaired somatosensory integration and for PLM pattern generation [16]. An altered motor cortical excitability and defective cortical integration of sensory and motor information, which can be reverted by dopaminergic treatment, have also been proposed to explain the urge to move which characterizes the RLS [17-19].

In 2007, the rotigotine transdermal patch has been approved by the regulatory authorities in Europe for use in all stages of Parkinson's disease (PD), at doses of 2-8 mg/day for early PD and of $4-16 \mathrm{mg} /$ day for advanced PD patients. The marketing authorization for this indication originally granted by the FDA was suspended in 2008 due to crystal formation in the patches, but was granted again in 2012. At doses of 1,2 and $3 \mathrm{mg} / 24 \mathrm{~h}$, the rotigotine transdermal patch also received EMA marketing authorization for the treatment of adult patients with moderateto-severe RLS in August 2008, and FDA authorization in 2012. This review will focus on the rotigotine transdermal patch. Other options for the treatment of RLS will also be briefly reviewed, and the place which rotigotine patch treatment has among them will be highlighted.

\section{Pharmacodynamics and Pharmacokinetics of Rotigotine}

The pharmacodynamics and pharmacokinetics of rotigotine have been extensively reviewed elsewhere [52]. As there is no animal model of RLS, there are no preclinical data about the effect of rotigotine on this disease, although preliminary results about the pharmacokinetics of rotigotine in RLS have recently been published [20]. A total of 1,995 blood samples were taken from 284 patients included in a rotigotine clinical trial [21] to quantify rotigotine plasma concentrations. The mean 24-hour rotigotine plasma concentrations showed a linear dose relationship and remained mainly unchanged between the first and fifth year of treatment.

\section{Clinical Efficacy of Rotigotine}

A summary of the characteristics of published studies on rotigotine are provided in table 1. The efficacy and safety of rotigotine were initially investigated in a small sample of patients with moderate-to-severe RLS [22]. Three fixed doses of rotigotine $(1.125,2.25$ and $4.5 \mathrm{mg})$ and placebo were applied by patches in a double-blind, randomized, parallel-group, multicenter, 1-week proof-of-concept study. The primary efficacy measure was the total score on the International Restless Legs Syndrome Scale (IRLS). Additionally, the RLS-6 scales, the Clinical Global Impression (CGI) scale and a sleep diary were used. Sixty-three patients were randomly assigned to the four groups. In the placebo group, a marked change of 8 points from baseline was noted; however, the improvement in the severity of RLS symptoms was much more pronounced, i.e. by $>10$ points, in all rotigotine groups. In the highest-dose group ( $4.5 \mathrm{mg} /$ day of rotigotine), the improvement was almost twice as high (15.7 points) as in the placebo group $(p=0.0095)$. According to the RLS-6 scales, daytime symptoms significantly improved with all rotigotine doses. The CGI items supported the favorable efficacy of the 4.5-mg dose.

The efficacy and safety of the rotigotine transdermal patch were further tested in a double-blind, randomized, parallel-group, multicenter, 6-week dose-finding trial [23]. The primary efficacy measure was the total score on the IRLS. In addition, the RLS- 6 scales and the CGI scale were administered. A total of 341 patients were randomized to receive placebo or $0.5,1.0,2.0,3.0$ or $4.0 \mathrm{mg} /$ day of rotigotine. The IRLS total score improved by $-10.6,-15.1$, $-15.7,-17.5$ and -14.8 with increasing rotigotine doses versus -9.2 with placebo between 
Table 1. Studies on rotigotine in RLS

\begin{tabular}{|c|c|c|c|c|c|c|c|}
\hline First author & $\begin{array}{l}\text { Study } \\
\text { design }\end{array}$ & $\begin{array}{l}\text { Sample } \\
\text { characteristics }\end{array}$ & $\begin{array}{l}\text { Sample } \\
\text { size, } \mathrm{n}\end{array}$ & $\begin{array}{l}\text { Rotigotine dose, } \\
\text { mg/day }\end{array}$ & $\begin{array}{l}\text { Treatment } \\
\text { duration }\end{array}$ & $\begin{array}{l}\text { Primary } \\
\text { outcomes }\end{array}$ & $\begin{array}{l}\text { Secondary } \\
\text { outcomes }\end{array}$ \\
\hline $\begin{array}{l}\text { Stiasny-Kolster } \\
{[22], 2004}\end{array}$ & $\begin{array}{l}\text { R, DB, PC, } \\
\text { MC, P, RI }\end{array}$ & $\begin{array}{l}\text { Idiopathic RLS, IRLS } \\
\text { score } \geq 10\end{array}$ & 63 & $1.125,2.25,4.5$ & 1 week & $\begin{array}{l}\text { Change in } \\
\text { IRLS score }\end{array}$ & $\begin{array}{l}\text { RLS-6 scales, CGI, } \\
\text { safety }\end{array}$ \\
\hline $\begin{array}{l}\text { Oertel [23], } \\
2008\end{array}$ & $\begin{array}{l}\text { R, DB, PC, } \\
\text { MC, P, RI }\end{array}$ & Idiopathic RLS & 341 & $\begin{array}{l}0.5,1.0,2.0 \\
3.0,4.0\end{array}$ & 6 weeks & $\begin{array}{l}\text { Change in } \\
\text { IRLS score }\end{array}$ & $\begin{array}{l}\text { RLS-6 scales, CGI, } \\
\text { safety }\end{array}$ \\
\hline $\begin{array}{l}\text { Oertel [21], } \\
2008\end{array}$ & O, UC, MC & Idiopathic RLS & 295 & $\begin{array}{l}0.5,1.0,2.0 \\
3.0,4.0\end{array}$ & 12 months & Safety & Change in IRLS score \\
\hline $\begin{array}{l}\text { Högl [24], } \\
2010\end{array}$ & O, UC, MC & Idiopathic RLS & 190 & $\begin{array}{l}0.5,1.0,2.0 \\
3.0,4.0\end{array}$ & 24 months & Safety & Change in IRLS score \\
\hline $\begin{array}{l}\text { Trenkwalder } \\
{[26], 2008}\end{array}$ & $\begin{array}{l}\text { R, DB, PC, } \\
\text { MC, P }\end{array}$ & $\begin{array}{l}\text { Idiopathic RLS, IRLS } \\
\text { score }>15\end{array}$ & 458 & $1.0,2.0,3.0$ & 6 months & $\begin{array}{l}\text { Change in } \\
\text { IRLS/CGI-1 } \\
\text { score }\end{array}$ & $\begin{array}{l}\text { Responder analysis, } \\
\text { RLS-6 scales, CGI-2/3, } \\
\text { safety }\end{array}$ \\
\hline $\begin{array}{l}\text { Hening [25], } \\
2010\end{array}$ & $\begin{array}{l}\text { R, DB, PC, } \\
\text { MC, P }\end{array}$ & $\begin{array}{l}\text { Idiopathic RLS, IRLS } \\
\text { score }>15\end{array}$ & 505 & $\begin{array}{l}0.5,1.0,2.0 \\
3.0\end{array}$ & 6 months & $\begin{array}{l}\text { Change in } \\
\text { IRLS/CGI-1 } \\
\text { score }\end{array}$ & $\begin{array}{l}\text { Responder analysis, } \\
\text { RLS-6 scales, CGI-2/3, } \\
\text { safety }\end{array}$ \\
\hline $\begin{array}{l}\text { Oertel [30], } \\
2010\end{array}$ & $\begin{array}{l}\text { R, DB, PC, } \\
\text { MC, P }\end{array}$ & $\begin{array}{l}\text { Idiopathic RLS, IRLS } \\
\text { score }>15\end{array}$ & 67 & $1.0,2.0,3.0$ & 6 weeks & PLMI (PSG) & $\begin{array}{l}\text { Change in IRLS score, } \\
\text { RLS-6 scales, safety }\end{array}$ \\
\hline
\end{tabular}

$\mathrm{R}=$ Randomized; $\mathrm{DB}=$ double-blind; $\mathrm{PC}=$ placebo-controlled; $\mathrm{MC}=$ multicenter; $\mathrm{P}$ = parallel; $\mathrm{RI}$ = initial run-in phase; $\mathrm{O}$ = open-label extension; $\mathrm{UC}=$ uncontrolled; $\mathrm{PSG}$ = polysomnography.

baseline and the end of the 6-week treatment period. The hierarchical statistical test procedure demonstrated a superiority of rotigotine over placebo for 4, 3, 2 and $1 \mathrm{mg} / 24 \mathrm{~h}$ (p values of $0.0013,<0.0001,0.0003$ and 0.0004 , respectively). The RLS-6 and CGI scale scores showed essentially the same results. According to the RLS Quality of Life Questionnaire (QoL-RLS), quality of life increased in all treatment groups beyond $0.5 \mathrm{mg} / 24 \mathrm{~h}$ compared with placebo, with a greater benefit in the two highest-rotigotine-dose groups.

Of the 310 patients who finished the abovementioned controlled trial, 295 were entered in an open-label uncontrolled extension trial [21]. At the end of the first year of follow-up, the mean daily dose was $2.8 \pm 1.2 \mathrm{mg} / 24 \mathrm{~h}$, with $4 \mathrm{mg} / 24 \mathrm{~h}$ being the most frequently applied dose $(40.6 \%)$. The IRLS total score improved by $-17.4 \pm 9.9$ points between baseline and the end of year $1(\mathrm{p}<0.001)$. Follow-up information at the end of year 2 was available for 190 out of the 295 patients who finished the double-blind controlled trial [24]. The mean daily rotigotine dose after 2 years was $2.93 \pm 1.14 \mathrm{mg} / 24 \mathrm{~h}$, with a $2.9 \%$ dose increase from year 1 . The IRLS total score improved by $-17.2 \pm 9.2$ from baseline to year 2 .

Two other large, randomized, double-blind, placebo-controlled trials have also been published $[25,26]$. In the first one, Trenkwalder et al. [26] treated 458 patients with placebo or 1,2 or $3 \mathrm{mg} /$ day of rotigotine for 6 months. In the other one, Hening et al. [25] did the same with 505 patients, except that a $0.5 \mathrm{mg} /$ day arm was included. Trenkwalder et al. [26] observed that the mean change in the IRLS sum score from baseline at the end of the maintenance phase was $-13.7 \pm 0.9$ in the 1 -mg group, $-16.2 \pm 0.9$ in the 2 -mg group and $-16.8 \pm 0.9$ in the 3-mg group versus $-8.6 \pm 0.9$ in the placebo group ( $p<0.0001$ for treatment difference vs. placebo for each dose). The mean change in CGI item 1 score from baseline at the end of the maintenance phase was $-2.09 \pm 0.14$ in the 1-mg group, $-2.41 \pm 0.14$ in the 2-mg group and $-2.55 \pm 0.14$ in the $3-\mathrm{mg}$ group versus $-1.34 \pm 0.14$ in the placebo group $(\mathrm{p}<0.0001$ for treatment difference vs. placebo with each dose). The results from the trial by Hening et al. [25] were essentially similar, except that no difference between placebo and the doses of 0.5 or $1 \mathrm{mg} /$ day were found. Trenkwalder et al. [26] also observed that the mean changes in 


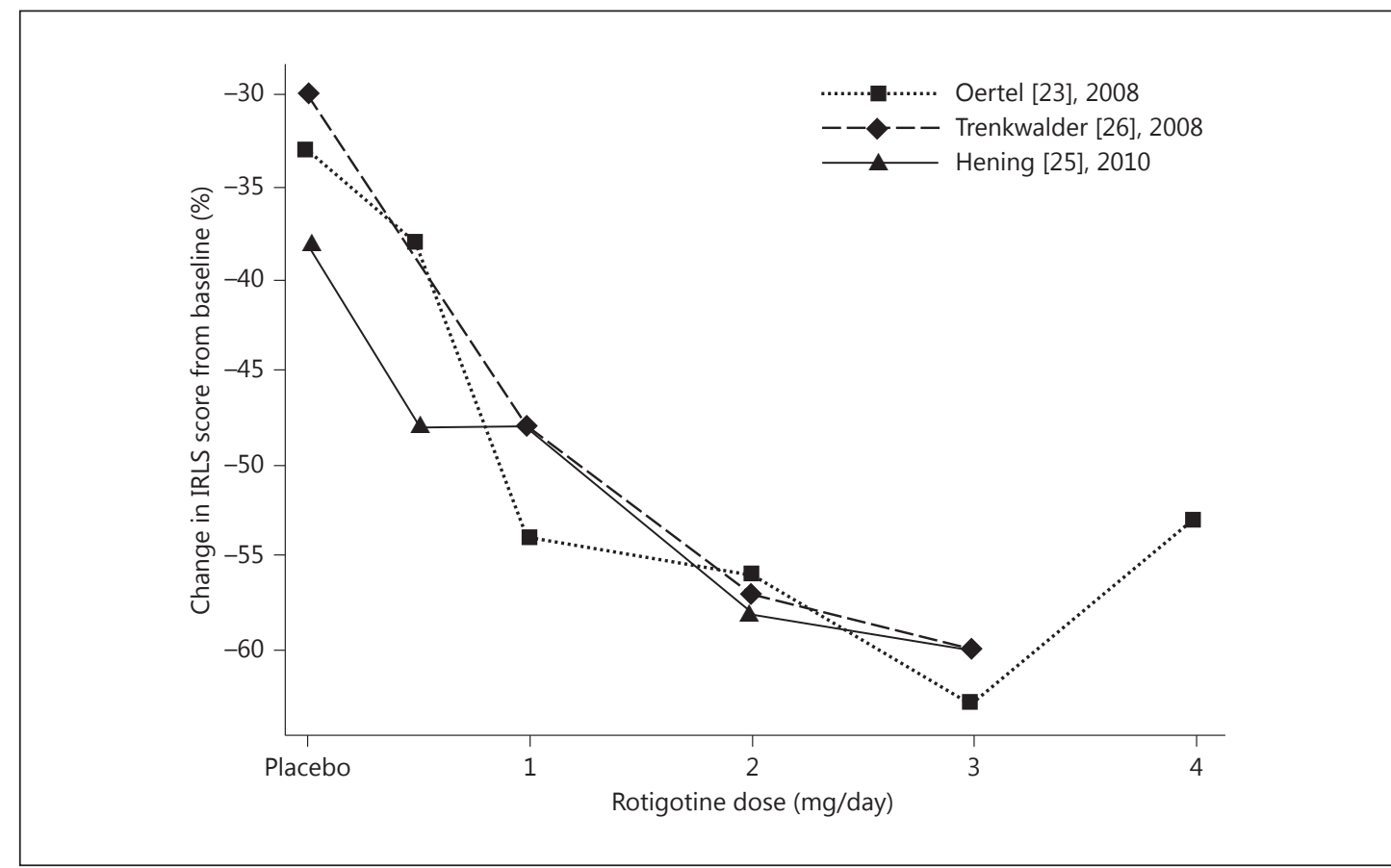

Fig. 1. Change in IRLS score from baseline in pivotal double-blind, placebo-controlled rotigotine efficacy studies on RLS patients lasting $\geq 6$ weeks. Significant differences from placebo were observed with doses of $\geq 1 \mathrm{mg} /$ day.

RLS-QoL sum score from baseline at the end of the maintenance phase were $-13.1 \pm 14.8$ in the 1-mg group, $-15.7 \pm 12.8$ in the 2 -mg group and $-17.5 \pm 4.2$ in the 3 -mg group versus -7.3 \pm 13.5 in the placebo group, thus suggesting a dose response in the improvement of the quality-of-life score after rotigotine. Rotigotine was also shown to significantly improve daytime functioning, daytime symptoms, mood disturbances and depressive symptoms, and to reduce impairment of daily activities due to pain in post hoc analyses [27-29].

The dose-related efficacy across the three abovementioned pivotal, double-blind, randomized studies employing the IRLS as their primary efficacy criterion and lasting $\geq 6$ weeks $[23,25,26]$ is shown in figure 1 . A simple look at the figure suggests that the maximal efficacy is attained with $3 \mathrm{mg} /$ day of rotigotine.

Finally, a randomized, placebo-controlled polysomnographic study was conducted on subjects with moderate-to-severe RLS and PLM to assess the efficacy of rotigotine in ameliorating the latter [30]. The mean PLM index (PLMI; PLM per hour of time in bed) decreased more with rotigotine (from 50.9 to $8.1 / \mathrm{h}$ ) than with placebo (from 37.4 to $27.1 / \mathrm{h}$; adjusted treatment ratio $=4.25 ; 95 \% \mathrm{CI}: 2.48-7.28 ; \mathrm{p}<0.0001$ ). At the end of the maintenance phase, $39 \%$ of the rotigotine subjects had PLMI levels of $<5 / \mathrm{h}$, and $26 \%$ showed no RLS symptoms (IRLS score 0), whereas no placebo subject met these criteria.

\section{Safety and Tolerability}

The safety data from the pivotal double-blind, placebo-controlled, randomized studies are shown in table $2[23,25,26]$. Overall, no major safety concerns were found in both doubleblind and long-term open-label studies. The most frequent adverse events were application 
Table 2. Safety findings from pivotal double-blind, placebo-controlled, randomized RLS trials lasting $\geq 6$ weeks $(\%)$

\begin{tabular}{|c|c|c|c|c|c|c|c|}
\hline & $\begin{array}{l}\text { Any } \\
\mathrm{AE}\end{array}$ & $\begin{array}{l}\text { Application } \\
\text { site reactions }\end{array}$ & $\begin{array}{l}\text { Nausea/ } \\
\text { vomiting }\end{array}$ & Headache & Fatigue & $\begin{array}{l}\text { Somno- } \\
\text { lence }\end{array}$ & Dizziness \\
\hline \multicolumn{8}{|l|}{ Oertel [23], 2008} \\
\hline Placebo $(n=55)$ & 45 & 2 & 9 & 7 & 9 & - & 7 \\
\hline R $0.5 \mathrm{mg}(\mathrm{n}=51)$ & 65 & 10 & 6 & 12 & 4 & - & 2 \\
\hline $\mathrm{R} 1 \mathrm{mg}(\mathrm{n}=64)$ & 48 & 16 & 9 & 8 & 5 & - & 2 \\
\hline R $2 \operatorname{mg}(n=49)$ & 57 & 16 & 6 & 2 & 6 & - & 6 \\
\hline R $3 \mathrm{mg}(\mathrm{n}=65)$ & 75 & 20 & 25 & 5 & 11 & - & 6 \\
\hline $\mathrm{R} 4 \mathrm{mg}(\mathrm{n}=56)$ & 62 & 25 & 23 & 12 & 7 & - & 5 \\
\hline \multicolumn{8}{|c|}{ Trenkwalder [26], 2008} \\
\hline Placebo $(n=117)$ & 55 & 2 & 3 & 7 & 9 & - & 3 \\
\hline $\mathrm{R} 1 \mathrm{mg}(\mathrm{n}=115)$ & 73 & 35 & 9 & 10 & 7 & - & 4 \\
\hline $\mathrm{R} 2 \mathrm{mg}(\mathrm{n}=112)$ & 80 & 41 & 21 & 13 & 15 & - & 7 \\
\hline R $3 \mathrm{mg}(\mathrm{n}=114)$ & 80 & 52 & 18 & 16 & 11 & - & 4 \\
\hline \multicolumn{8}{|l|}{ Hening [25], 2010} \\
\hline Placebo $(n=100)$ & 84 & 5 & 10 & 8 & 4 & 6 & 6 \\
\hline R $0.5 \mathrm{mg}(\mathrm{n}=99)$ & 85 & 22 & 13 & 14 & 10 & 8 & 4 \\
\hline R $1 \mathrm{mg}(\mathrm{n}=100)$ & 88 & 17 & 20 & 12 & 3 & 10 & 3 \\
\hline R $2 \mathrm{mg}(\mathrm{n}=99)$ & 90 & 34 & 18 & 10 & 7 & 13 & 7 \\
\hline R $3 \mathrm{mg}(\mathrm{n}=106)$ & 89 & 34 & 21 & 10 & 7 & 15 & 7 \\
\hline
\end{tabular}

site reactions, nausea/vomiting or headache. Generally, application site reactions were cited as the most common adverse events in the rotigotine clinical studies [23, 25, 26]. Between 25 and $52 \%$ of the patients on the highest dose of rotigotine had application site reactions (including erythema, pruritus and dermatitis), in comparison with $2-5 \%$ of the patients receiving placebo treatment. However, the majority of these events were rated as mild to moderate and appeared to be dose related only for the moderate-to-severe site reactions. The occurrence of some dopaminergic adverse events such as nausea and vomiting appeared dose related, while other adverse events, including dizziness, showed no differences in occurrence between rotigotine- and placebo-treated patients [23, 25, 26].

Long-term safety was explored in the aforementioned open-label study [21], where 79\% of the patients experienced adverse events after 12 months of treatment with rotigotine. Skin reactions at the application sites of the patches were reported in $40 \%$ of the patients. Some serious dopaminergic adverse events were noted. Three patients reported sleep attacks or sudden onset of sleep (under 2 and $3 \mathrm{mg} / 24 \mathrm{~h}$ of rotigotine), and 1 patient reported hallucinations (under $2 \mathrm{mg} / 24 \mathrm{~h}$ of rotigotine). During the second year of follow-up, 131 of 220 patients (59.6\%) experienced adverse events [24]. Application site reactions occurred in $16.4 \%$ of the patients. There were 2 cases of somnolence, 5 of depression, 1 of insomnia and 2 of parasomnia, among others.

Occurrence of augmentation was assessed by a preliminary version of the Augmentation Severity Rating Scale in two large trials $[25,26]$ or by unsolicited reports by the patients and their documentation by the investigator in all the RLS studies [23, 25, 26]. In general, no signs of augmentation were noted. A retrospective reanalysis of the data by predefined board members employing criteria based on the IRLS showed a clinically relevant augmentation in 1.5 or $0.5 \%$ of rotigotine- or placebo-treated patients in a 6-month double-blind study [25], and in $2.9 \%$ over 12 months in an open-label follow-up study [21]. Five-year follow-up data 
Table 3. Comparison of rotigotine safety profiles between PD and RLS studies (n)

\begin{tabular}{lcccc}
\hline & $\begin{array}{c}\text { Application site } \\
\text { reactions }\end{array}$ & Dizziness & Nausea/vomiting & Somnolence \\
\hline RLS studies & & & & \\
Placebo & $7 / 217(3 \%)^{* *}$ & $10 / 217(4 \%)^{* *}$ & $14 / 217(6 \%)^{* *}$ & $6 / 100(6 \%)^{* *}$ \\
R 0.5 mg/day & $22 / 99(22 \%)$ & $4 / 99(4 \%)$ & $13 / 99(13 \%)$ & $8 / 99(8 \%)$ \\
R 1 mg/day & $57 / 215(27 \%)$ & $8 / 215(4 \%)$ & $30 / 215(14 \%)$ & $10 / 100(10 \%)$ \\
R 2 mg/day & $80 / 211(38 \%)$ & $15 / 211(7 \%)$ & $41 / 211(20 \%)$ & $13 / 99(13 \%)$ \\
R 3 mg/day & $95 / 220(43 \%)$ & $12 / 220(5 \%)$ & $43 / 220(19 \%)$ & $16 / 106(15 \%)$ \\
PD studies & & & & \\
Placebo & $44 / 435(10 \%)$ & $46 / 435(11 \%)$ & $70 / 435(16 \%)$ & $84 / 435(19 \%)$ \\
R 6 mg/day & $80 / 181(44 \%)$ & $34 / 181(19 \%)$ & $74 / 181(41 \%)$ & $60 / 181(33 \%)$ \\
R 8 mg/day & $124 / 333(37 \%)$ & $57 / 333(17 \%)$ & $95 / 333(29 \%)$ & $87 / 333(26 \%)$ \\
R 12 mg/day & $51 / 111(46 \%)$ & $17 / 111(15 \%)$ & $27 / 111(24 \%)$ & $36 / 111(32 \%)$ \\
R 16 mg/day ${ }^{1}$ & $37 / 204(18 \%)$ & $12 / 204(6 \%)$ & $35 / 204(17 \%)$ & $24 / 204(12 \%)$ \\
\hline
\end{tabular}

Data were extracted from Hening et al. [25] (2010), Trenkwalder et al. [26] (2008), Jankovic et al. [33] (2007), Watts et al. [34] (2007), Giladi et al. [35] (2007), LeWitt et al. [36] (2007) and Poewe et al. [37] (2007). $\mathrm{R}=$ Rotigotine. ${ }^{* *} \mathrm{p}<0.01$ vs. placebo groups in PD studies ( $\chi^{2}$ test).

${ }^{1}$ The frequency of adverse events in the study by Poewe et al. [37] was lower than in the other trials.

have recently been published in abstract form. Out of the 295 patients who originally entered an open-label extension trial [21], 126 were monitored for up to 5 years [31]. Patients who met the Max Planck Institute (MPI) diagnostic criteria for augmentation [32], or who had discontinued the study because of loss of efficacy, were further examined by an international expert panel for definite confirmation and clinical evaluation. The MPI criteria for augmentation were met by 145 patients (49.2\%); the diagnosis was confirmed in 69 patients $(24.3 \%)$ and clinical significance in 39 patients (13.2\%). Discontinuation due to augmentation occurred in 12 cases (4.1\%). Of all the patients with clinically significant augmentation, $61 \%$ were on $4 \mathrm{mg} /$ day of rotigotine, which is a nonapproved dose. Interestingly, in $61 \%$ of the patients, the first episode took place after 1 year of treatment. While the frequency of augmentation decreased over time, new episodes were more frequently clinically significant.

\section{Comparison of Rotigotine's Safety Profiles for PD and RLS}

It is interesting to further compare the safety profiles of rotigotine between PD and RLS studies. Frequencies of application site reactions or of some of the most frequent dopaminergic adverse drug reactions were extracted, if available, from rotigotine PD [33-37] or RLS studies $[25,26]$ lasting $\geq 6$ months. This analysis was complicated by differential adverse event reporting in the trials reviewed. The results are shown in table 3 . In the first place, the frequencies of the recorded adverse events were compared between the placebo groups of the PD and RLS studies. Application site reactions, dizziness, nausea/vomiting and somnolence were less frequently observed with placebo in the RLS studies compared with the same group in the PD studies (all $p<0.01$ ). The differences in the frequencies of dopaminergic adverse drug reactions between the two groups could possibly be explained by differences in the consumption of other antiparkinsonian medications. Conversely, there is no clear explanation for the difference in the frequency of application site reactions. These results indicate that the reason why PD patients on placebo report adverse events more frequently than do RLS patients may not be related to medications or the disease itself but to other unknown factors. 
Table 4. Most relevant clinical treatment efficacy trials of RLS

\begin{tabular}{|c|c|c|c|c|c|c|c|c|}
\hline First author & $\begin{array}{l}\text { Study } \\
\text { design }\end{array}$ & $\begin{array}{l}\text { Sample } \\
\text { size, } \mathrm{n}\end{array}$ & Patients & $\begin{array}{l}\text { Duration, } \\
\text { weeks }\end{array}$ & $\begin{array}{l}\text { Drug and daily } \\
\text { dose, mg/day }\end{array}$ & $\begin{array}{l}\text { Comparator and } \\
\text { dose, } \mathrm{mg} / \text { day }\end{array}$ & $\begin{array}{l}\text { Primary } \\
\text { outcome }\end{array}$ & Results \\
\hline \multicolumn{9}{|c|}{ Dopamine agonists } \\
\hline $\begin{array}{l}\text { Walters [40], } \\
2004\end{array}$ & $\begin{array}{l}\mathrm{R}, \mathrm{DB}, \mathrm{C}, \\
\mathrm{MC}\end{array}$ & 267 & Primary RLS & 12 & $\begin{array}{l}\text { Ropinirole; } \\
0.25-4\end{array}$ & Placebo & $\begin{array}{l}\text { IRLS } \\
\text { score }\end{array}$ & -47 vs. $-35 \%$ \\
\hline $\begin{array}{l}\text { Bogan [38], } \\
2006\end{array}$ & $\begin{array}{l}\mathrm{R}, \mathrm{DB}, \mathrm{C} \\
\mathrm{MC}\end{array}$ & 381 & Primary RLS & 12 & $\begin{array}{l}\text { Ropinirole; } \\
0.25-4\end{array}$ & Placebo & $\begin{array}{l}\text { IRLS } \\
\text { score }\end{array}$ & -61 vs. $-45 \%$ \\
\hline $\begin{array}{l}\text { Kushida [39], } \\
2008\end{array}$ & $\begin{array}{l}\text { R, DB, C, } \\
\text { MC }\end{array}$ & 359 & Primary RLS & 12 & $\begin{array}{l}\text { Ropinirole; } \\
0.25-6\end{array}$ & Placebo & $\begin{array}{l}\text { IRLS } \\
\text { score }\end{array}$ & -58 vs. $-42 \%$ \\
\hline $\begin{array}{l}\text { Partinen [43], } \\
2006\end{array}$ & $\begin{array}{l}\mathrm{R}, \mathrm{DB}, \mathrm{C}, \\
\mathrm{MC}\end{array}$ & 109 & Primary RLS & 12 & $\begin{array}{l}\text { Pramipexole; } \\
0.125,0.25 \\
0.50,0.7\end{array}$ & Placebo & $\begin{array}{l}\text { IRLS } \\
\text { score }\end{array}$ & $\begin{array}{l}-53,-66,-72 \text { and } \\
-70 \text { vs. }-30 \%\end{array}$ \\
\hline $\begin{array}{l}\text { Oertel [42], } \\
2007\end{array}$ & $\begin{array}{l}\text { R, DB, C, } \\
\text { MC }\end{array}$ & 345 & Primary RLS & 6 & $\begin{array}{l}\text { Pramipexole; } \\
\text { up to } 0.75\end{array}$ & Placebo & $\begin{array}{l}\text { IRLS } \\
\text { score }\end{array}$ & -50 vs. $-29 \%$ \\
\hline $\begin{array}{l}\text { Oertel [51], } \\
2006\end{array}$ & $\begin{array}{l}\text { R, DB, C, } \\
\text { MC }\end{array}$ & 43 & Primary RLS & 5 & Cabergoline; 2 & Placebo & $\begin{array}{l}\text { IRLS } \\
\text { score }\end{array}$ & -75 vs. $-25 \%$ \\
\hline $\begin{array}{l}\text { Trenkwalder } \\
{[41], 2007}\end{array}$ & $\begin{array}{l}\mathrm{R}, \mathrm{DB}, \mathrm{C} \\
\mathrm{MC}\end{array}$ & 418 & Primary RLS & 30 & Cabergoline; 2 & $\begin{array}{l}\text { Levodopa; } \\
200\end{array}$ & $\begin{array}{l}\text { IRLS } \\
\text { score }\end{array}$ & $\begin{array}{c}-61 \text { vs. }-34 \% \\
(p<0.001)\end{array}$ \\
\hline \multicolumn{9}{|l|}{ Anticonvulsants } \\
\hline $\begin{array}{l}\text { Allen [45], } \\
2010\end{array}$ & $\mathrm{R}, \mathrm{DB}, \mathrm{C}$ & 137 & Primary RLS & 6 & $\begin{array}{l}\text { Pregabalin; } \\
50,100,150 \text {, } \\
300,450\end{array}$ & Placebo & $\begin{array}{l}\text { IRLS } \\
\text { score }\end{array}$ & $\begin{array}{r}-48,-47,-61,-51 \\
\text { and }-67 \text { vs. }-33 \%\end{array}$ \\
\hline $\begin{array}{l}\text { Garcia- } \\
\text { Borreguero } \\
{[46], 2010}\end{array}$ & $\mathrm{R}, \mathrm{DB}, \mathrm{C}$ & 58 & Primary RLS & 12 & $\begin{array}{l}\text { Pregabalin; } \\
322\end{array}$ & Placebo & $\begin{array}{l}\text { IRLS } \\
\text { score }\end{array}$ & -65 vs. $-52 \%$ \\
\hline $\begin{array}{l}\text { Garcia- } \\
\text { Borreguero } \\
{[44], 2002}\end{array}$ & $\mathrm{R}, \mathrm{DB}, \mathrm{CO}$ & 24 & $\begin{array}{l}\text { Primary/ } \\
\text { secondary RLS }\end{array}$ & 6 & $\begin{array}{l}\text { Gabapentin; } \\
1,855\end{array}$ & Placebo & $\begin{array}{l}\text { IRLS } \\
\text { score }\end{array}$ & -50 vs. $-10 \%$ \\
\hline $\begin{array}{l}\text { Happe [48], } \\
2003\end{array}$ & Pragmatic & 16 & Primary RLS & 4 & $\begin{array}{l}\text { Gabapentin; } \\
300-1,200\end{array}$ & $\begin{array}{l}\text { Ropinirole; } \\
0.25-1.5\end{array}$ & $\begin{array}{l}\text { IRLS } \\
\text { score }\end{array}$ & -41 vs. $-51 \%$ \\
\hline \multicolumn{9}{|l|}{ Iron } \\
\hline $\begin{array}{l}\text { Davis [47], } \\
2000\end{array}$ & $\mathrm{R}, \mathrm{DB}, \mathrm{C}$ & 28 & Primary RLS & 12 & $\begin{array}{l}\text { Iron sulfate; } \\
650\end{array}$ & Placebo & $\begin{array}{l}\text { Sleep } \\
\text { quality VAS }\end{array}$ & S -13 vs. $-5 \%$ \\
\hline $\begin{array}{l}\text { Wang [49], } \\
2009\end{array}$ & $\mathrm{R}, \mathrm{DB}, \mathrm{C}$ & 18 & $\begin{array}{l}\text { Iron } \\
\text { deficiency RLS }\end{array}$ & 12 & $\begin{array}{l}\text { Iron sulfate; } \\
650\end{array}$ & Placebo & $\begin{array}{l}\text { IRLS } \\
\text { score }\end{array}$ & -41 vs. $6 \%$ \\
\hline
\end{tabular}

$\mathrm{R}=$ Randomized; $\mathrm{DB}=$ double-blind $\mathrm{C}=$ controlled; $\mathrm{MC}=$ multicenter; $\mathrm{CO}=$ crossover; $\mathrm{VAS}=$ visual analog scale.

A further look at table 3 reveals that dopaminergic adverse events, but not application site reactions, are more frequent in rotigotine-treated PD patients than in rotigotine-treated RLS patients. In general, the PD studies used higher rotigotine doses than the RLS studies, which could explain the aforementioned differences. Nonetheless, it should also be kept in mind that PD patients in the main may be more prone to report adverse events than RLS patients.

\section{The Place of Rotigotine in the Treatment of RLS}

Other pharmacological options for RLS treatment have been investigated in several clinical trials, many of which were randomized and controlled (table 4). The parameter most frequently evaluated was the IRLS score. Dopaminergic agonists are the first-line agents for the treatment of RLS symptoms [14]. Several randomized controlled studies showed significant changes if patients were treated with $0.25-6 \mathrm{mg} /$ day of ropinirole for 4-12 weeks 
(table 4) [38-40]. The efficacy of ergot agonists such as cabergoline ( $2 \mathrm{mg}$ ) was demonstrated in studies employing levodopa as the active comparator [41]. Treatment with 0.125-0.75 $\mathrm{mg}$ /day of pramipexole was also explored, with positive results $[42,43]$. In general, the safety profiles were good, but these drugs can lead to severe adverse events such as diurnal somnolence, impulse control disorders and augmentation in some patients [44]. Cabergoline is a second-line therapy as ergot dopamine agonists have been shown to increase the risk of fibrotic adverse events. The efficacy of rotigotine (fig. 1) appears to be comparable to that of the other agonists for this indication.

In an attempt to find equally effective drugs but without the aforementioned tolerability issues, other drug treatment options have been explored, but there are no head-to-head comparisons of different active agents. The dose-related efficacy of pregabalin (50-450 mg/ day) was demonstrated in randomized, controlled studies [45, 46]. Gabapentin $(>1,300 \mathrm{mg} /$ day) was efficacious as compared with placebo in a randomized, double-blind crossover study [47]. Gabapentin effects appear to be similar to those of dopamine agonists. Results from a small head-to-head pragmatic study comparing gabapentin $(\leq 1,200 \mathrm{mg})$ with ropinirole $(\leq 1.5 \mathrm{mg}$ ) showed that these treatments may demonstrate a comparable efficacy (table 4) [48]. The efficacy of iron supplements was tested in primary or iron-deficient RLS patients (table 4). Improvements were observed in iron-deficient patients [49], but not in primary RLS patients [47].

\section{Conclusions}

Rotigotine is a $D_{1}-D_{5}$ receptor agonist, with the highest affinity for the $D_{3}$ receptor. The rotigotine transdermal patch has demonstrated its clinical efficacy for the treatment of RLS. The tolerability of the rotigotine patch appears to be well within the range of what is known and expected from other dopamine agonists, except for application site reactions, which appear to be only mild to moderate in the majority of cases. Nonetheless, such reactions could limit the practicability of this therapy for a number of patients. Interestingly, application site reactions affect PD and RLS patients with a similar frequency, which appears not to be the case for dopaminergic adverse events such as nausea/vomiting, somnolence or dizziness (table 3). Moreover, impulse control disorders have been correlated with rotigotine administration in PD patients but not in RLS patients. This might be related to the dose. Nonetheless, as shown by the comparison of placebo-treated PD with placebo-treated RLS patients (table 3), PD patients may be more prone to disclose their adverse events independently of the drug and dose administered.

Rotigotine appears to provide relief to RLS patients (fig. 1) as compared with other treatments (table 4). Therefore, rotigotine can be considered a first-line treatment for RLS. In addition, the transdermal application of rotigotine may offer some advantages beyond those of many of the alternative oral pharmacological options, such as the provision of stable plasmatic levels during $24 \mathrm{~h}$. Such an advantage may be of special interest to RLS patients suffering from both nocturnal and diurnal symptoms as it could contribute to reducing augmentation. A recent study suggested that long-acting dopamine agonists, preferably with $D_{2}$ and $D_{3}$ receptor affinity, may reduce the augmentation risk [50]. Rotigotine might be a good option for offering symptomatic relief from RLS with a low risk of augmentation. Nonetheless, as this issue has not been sufficiently evaluated in long-term trials, any conclusion is speculative. As a final advantage, the once-daily transdermal patch formulation may favor compliance by providing a convenient means of administration. 


\section{Disclosure Statement}

S.P.-L., M.V.R. and P.L.R. have no financial conflicts or competing interests to disclose. O.R. has acted as a scientific advisor for most drug companies developing antiparkinsonian medications (Abbott, GlaxoSmithKline, Novartis, Boehringer Ingelheim, Impax, Oxford BioMedica, Lundbeck, TEVA and UCB) and has received unrestricted scientific grants from academic nonprofit entities (Toulouse University Hospital, French Health Ministry, Michael J. Fox Foundation, France Parkinson) and pharmaceutical companies developing or marketing antiparkinsonian medications.

\section{References}

1 Allen RP, Bharmal M, Calloway M: Prevalence and disease burden of primary restless legs syndrome: results of a general population survey in the United States. Mov Disord 2011;26:114-120.

-2 Allen RP, Picchietti D, Hening WA, Trenkwalder C, Walters AS, Montplaisi J: Restless legs syndrome: diagnostic criteria, special considerations, and epidemiology. A report from the restless legs syndrome diagnosis and epidemiology workshop at the National Institutes of Health. Sleep Med 2003;4:101-119.

-3 Winkelmann J, Muller-Myhsok B, Wittchen HU, Hock B, Prager M, Pfister H, Strohle A, Eisensehr I, Dichgans M, Gasser T, Trenkwalder C: Complex segregation analysis of restless legs syndrome provides evidence for an autosomal dominant mode of inheritance in early age at onset families. Ann Neurol 2002;52:297-302.

-4 Hening WA, Walters AS, Wagner M, Rosen R, Chen V, Kim S, Shah M, Thai O: Circadian rhythm of motor restlessness and sensory symptoms in the idiopathic restless legs syndrome. Sleep 1999;22:901-912.

-5 Trenkwalder C, Hening WA, Walters AS, Campbell SS, Rahman K, Chokroverty S: Circadian rhythm of periodic limb movements and sensory symptoms of restless legs syndrome. Mov Disord 1999;14:102-110.

6 Montplaisir J, Boucher S, Poirier G, Lavigne G, Lapierre O, Lesperance P: Clinical, polysomnographic, and genetic characteristics of restless legs syndrome: a study of 133 patients diagnosed with new standard criteria. Mov Disord 1997;12:61-65.

7 Allen RP, Walters AS, Montplaisir J, Hening W, Myers A, Bell TJ, Ferini-Strambi L: Restless legs syndrome prevalence and impact: REST general population study. Arch Intern Med 2005;165:1286-1292.

-8 Pearson VE, Allen RP, Dean T, Gamaldo CE, Lesage SR, Earley CJ: Cognitive deficits associated with restless legs syndrome (RLS). Sleep Med 2006; 7:25-30.

-9 Jung KY, Koo YS, Kim BJ, Ko D, Lee GT, Kim KH, Im CH: Electrophysiologic disturbances during daytime in patients with restless legs syndrome: further evidence of cognitive dysfunction? Sleep Med 2011;12:416-421.

10 Elwood P, Hack M, Pickering J, Hughes J, Gallacher J: Sleep disturbance, stroke, and heart disease events: evidence from the Caerphilly cohort. J Epidemiol Community Health 2006;60:69-73.

11 Walters AS, Rye DB: Review of the relationship of restless legs syndrome and periodic limb movements in sleep to hypertension, heart disease, and stroke. Sleep 2009;32:589-597.

-12 Hoque R, Chesson AL Jr: Pharmacologically induced/exacerbated restless legs syndrome, periodic limb movements of sleep, and REM behavior disorder/REM sleep without atonia: literature review, qualitative scoring, and comparative analysis. J Clin Sleep Med 2010;6:79-83.

13 Scalise A: Patho-physiology of restless legs syndrome: a very tedious puzzle! Sleep Med 2009;10:1073-1074.

14 Garcia-Borreguero D, Stillman P, Benes H, Buschmann H, Chaudhuri KR, Gonzalez Rodriguez VM, Högl B, Kohnen R, Monti GC, Stiasny-Kolster K, Trenkwalder C, Williams AM, Zucconi M: Algorithms for the diagnosis and treatment of restless legs syndrome in primary care. BMC Neurol 2011;11:28.

15 Trenkwalder C, Paulus W, Walters AS: The restless legs syndrome. Lancet Neurol 2005;4:465-475.

-16 Paulus W, Dowling P, Rijsman R, Stiasny-Kolster K, Trenkwalder C, de Weerd A: Pathophysiological concepts of restless legs syndrome. Mov Disord 2007;22:1451-1456.

17 Rizzo V, Arico I, Liotta G, Ricciardi L, Mastroeni C, Morgante F, Allegra R, Condurso R, Girlanda P, Silvestri R, Quartarone A: Impairment of sensory-motor integration in patients affected by RLS. J Neurol 2010;257:19791985.

18 Stiasny-Kolster K, Haeske H, Tergau F, Muller HH, Braune HJ, Oertel WH: Cortical silent period is shortened in restless legs syndrome independently from circadian rhythm. Suppl Clin Neurophysiol 2003;56:381-389.

19 Tergau F, Wischer S, Paulus W: Motor system excitability in patients with restless legs syndrome. Neurology 1999;52:1060-1063.

20 Whitesides J, Cawello W, Braun M, Fichtner A, Oertel W: Stability of rotigotine plasma levels during long-term transdermal application for patients with idiopathic restless legs syndrome. Mov Disord 2011;26(suppl 2):S365.

-21 Oertel WH, Benes H, Garcia-Borreguero D, Geisler P, Högl B, Trenkwalder C, Tacken I, Schollmayer E, Kohnen $\mathrm{R}$, Stiasny-Kolster K: One year open-label safety and efficacy trial with rotigotine transdermal patch in moderate to severe idiopathic restless legs syndrome. Sleep Med 2008;9:865-873.

22 Stiasny-Kolster K, Kohnen R, Schollmayer E, Moller JC, Oertel WH: Patch application of the dopamine agonist rotigotine to patients with moderate to advanced stages of restless legs syndrome: a double-blind, placebocontrolled pilot study. Mov Disord 2004;19:1432-1438. 
-23 Oertel WH, Benes H, Garcia-Borreguero D, Geisler P, Högl B, Saletu B, Trenkwalder C, Sommerville KW, Schollmayer E, Kohnen R, Stiasny-Kolster K: Efficacy of rotigotine transdermal system in severe restless legs syndrome: a randomized, double-blind, placebo-controlled, six-week dose-finding trial in Europe. Sleep Med 2008;9:228-239.

24 Högl B, Oertel WH, Stiasny-Kolster K, Geisler P, Benes H, Garcia-Borreguero D, Trenkwalder C, Poewe W, Schollmayer E, Kohnen R: Treatment of moderate to severe restless legs syndrome: 2-year safety and efficacy of rotigotine transdermal patch. BMC Neurol 2010;10:86.

25 Hening WA, Allen RP, Ondo WG, Walters AS, Winkelman JW, Becker P, Bogan R, Fry JM, Kudrow DB, Lesh KW, Fichtner A, Schollmayer E: Rotigotine improves restless legs syndrome: a 6-month randomized, double-blind, placebo-controlled trial in the United States. Mov Disord 2010;25:1675-1683.

-26 Trenkwalder C, Benes H, Poewe W, Oertel WH, Garcia-Borreguero D, de Weerd AW, Ferini-Strambi L, Montagna P, Odin P, Stiasny-Kolster K, Högl B, Chaudhuri KR, Partinen M, Schollmayer E, Kohnen R: Efficacy of rotigotine for treatment of moderate-to-severe restless legs syndrome: a randomised, double-blind, placebo-controlled trial. Lancet Neurol 2008;7:595-604.

27 Benes H, Trenkwalder C, Grieger F, Schollmayer E, Moran K, Bauer L, Allen R, Kohnen R: Transdermal rotigotine improved mood disturbance and depressive symptoms due to restless legs syndrome (RLS) symptoms in patients with idiopathic RLS. Mov Disord 2011;26(suppl 2):S359-S360.

28 Kohnen R, Garcia-Borreguero D, Allen R, Grieger F, Bauer L, Schollmayer E, Trenkwalder C: Transdermal rotigotine improved daytime functioning and daytime symptoms in patients with idiopathic restless legs syndrome. Mov Disord 2011;26(suppl 2):S362.

29 Kohnen R, Garcia-Borreguero D, Moran K, Bauer L, Grieger F, Schollmayer E, Allen R, Stiasny-Kolster K: Transdermal rotigotine reduced impairment due to pain in RLS patients: a post hoc analysis of patients with moderate to extreme impairment due to pain. Mov Disord 2011;26(suppl 2):S361-S362.

-30 Oertel WH, Benes H, Garcia-Borreguero D, Högl B, Poewe W, Montagna P, Ferini-Strambi L, Sixel-Doring F, Trenkwalder C, Partinen M, Saletu B, Polo O, Fichtner A, Schollmayer E, Kohnen R, Cassel W, Penzel T, StiasnyKolster K: Rotigotine transdermal patch in moderate to severe idiopathic restless legs syndrome: a randomized, placebo-controlled polysomnographic study. Sleep Med 2010;11:848-856.

31 Kohnen R, Garcia-Borreguero D, Benes H, Ferini-Strambi L, Högl B, Oertel W, Trenkwalder C, Fichtner A, Schollmayer E: Augmentation of restless legs syndrome (RLS) under rotigotine: results from a 5-year prospective, multinational, open-label study. Mov Disord 2011;26(suppl 2):S361.

-32 Garcia-Borreguero D, Allen RP, Kohnen R, Högl B, Trenkwalder C, Oertel W, Hening WA, Paulus W, Rye D, Walters A, Winkelmann J, Earley CJ: Diagnostic standards for dopaminergic augmentation of restless legs syndrome: report from a World Association of Sleep Medicine-International Restless Legs Syndrome Study Group consensus conference at the Max Planck Institute. Sleep Med 2007;8:520-530.

-33 Jankovic J, Watts RL, Martin W, Boroojerdi B: Transdermal rotigotine: double-blind, placebo-controlled trial in Parkinson disease. Arch Neurol 2007;64:676-682.

-34 Watts RL, Jankovic J, Waters C, Rajput A, Boroojerdi B, Rao J: Randomized, blind, controlled trial of transdermal rotigotine in early Parkinson disease. Neurology 2007;68:272-276.

35 Giladi N, Boroojerdi B, Korczyn AD, Burn DJ, Clarke CE, Schapira AH: Rotigotine transdermal patch in early Parkinson's disease: a randomized, double-blind, controlled study versus placebo and ropinirole. Mov Disord 2007;22:2398-2404.

-36 LeWitt PA, Lyons KE, Pahwa R: Advanced Parkinson disease treated with rotigotine transdermal system: PREFER Study. Neurology 2007;68:1262-1267.

-37 Poewe WH, Rascol O, Quinn N, Tolosa E, Oertel WH, Martignoni E, Rupp M, Boroojerdi B: Efficacy of pramipexole and transdermal rotigotine in advanced Parkinson's disease: a double-blind, double-dummy, randomised controlled trial. Lancet Neurol 2007;6:513-520.

38 Bogan RK, Fry JM, Schmidt MH, Carson SW, Ritchie SY: Ropinirole in the treatment of patients with restless legs syndrome: a US-based randomized, double-blind, placebo-controlled clinical trial. Mayo Clin Proc 2006; 81:17-27.

-39 Kushida CA, Geyer J, Tolson JM, Asgharian A: Patient- and physician-rated measures demonstrate the effectiveness of ropinirole in the treatment of restless legs syndrome. Clin Neuropharmacol 2008;31:281-286.

-40 Walters AS, Ondo WG, Dreykluft T, Grunstein R, Lee D, Sethi K: Ropinirole is effective in the treatment of restless legs syndrome. TREAT RLS 2: a 12-week, double-blind, randomized, parallel-group, placebo-controlled study. Mov Disord 2004;19:1414-1423.

41 Trenkwalder C, Benes H, Grote L, Happe S, Högl B, Mathis J, Saletu-Zyhlarz GM, Kohnen R: Cabergoline compared to levodopa in the treatment of patients with severe restless legs syndrome: results from a multicenter, randomized, active controlled trial. Mov Disord 2007;22:696-703.

-42 Oertel WH, Stiasny-Kolster K, Bergtholdt B, Hallström Y, Albo J, Leissner L, Schindler T, Koester J, Reess J: Efficacy of pramipexole in restless legs syndrome: a six-week, multicenter, randomized, double-blind study (effect-RLS study). Mov Disord 2007;22:213-219.

43 Partinen M, Hirvonen K, Jama L, Alakuijala A, Hublin C, Tamminen I, Koester J, Reess J: Efficacy and safety of pramipexole in idiopathic restless legs syndrome: a polysomnographic dose-finding study - the PRELUDE study. Sleep Med 2006;7:407-417.

44 Garcia-Borreguero D, Larrosa O, de la Llave Y, Verger K, Masramon X, Hernandez G: Treatment of restless legs syndrome with gabapentin: a double-blind, cross-over study. Neurology 2002;59:1573-1579. 
45 Allen R, Chen C, Soaita A, Wohlberg C, Knapp L, Peterson BT, Garcia-Borreguero D, Miceli J: A randomized, double-blind, 6-week, dose-ranging study of pregabalin in patients with restless legs syndrome. Sleep Med 2010;11:512-519.

46 Garcia-Borreguero D, Larrosa O, Williams AM, Albares J, Pascual M, Palacios JC, Fernandez C: Treatment of restless legs syndrome with pregabalin: a double-blind, placebo-controlled study. Neurology 2010;74:18971904.

47 Davis BJ, Rajput A, Rajput ML, Aul EA, Eichhorn GR: A randomized, double-blind placebo-controlled trial of iron in restless legs syndrome. Eur Neurol 2000;43:70-75.

48 Happe S, Sauter C, Klosch G, Saletu B, Zeitlhofer J: Gabapentin versus ropinirole in the treatment of idiopathic restless legs syndrome. Neuropsychobiology 2003;48:82-86.

49 Wang J, O’Reilly B, Venkataraman R, Mysliwiec V, Mysliwiec A: Efficacy of oral iron in patients with restless legs syndrome and a low-normal ferritin: a randomized, double-blind, placebo-controlled study. Sleep Med 2009;10:973-975.

-50 Winkelman JW, Johnston L: Augmentation and tolerance with long-term pramipexole treatment of restless legs syndrome (RLS). Sleep Med 2004;5:9-14.

51 Oertel WH, Benes H, Bodenschatz R, Peglau I, Warmuth R, Happe S, Geisler P, Cassel W, Leroux M, Kohnen R, Stiasny-Kolster K: Efficacy of cabergoline in restless legs syndrome: a placebo-controlled study with polysomnography (CATOR). Neurology 2006;67:1040-1046.

52 Perez-Lloret S, Rey MV, Ratti PL, Rascol O: Rotigotine transdermal patch for the treatment of Parkinson's disease. Fundam Clin Pharmacol 2013;27:81-95. 